\title{
PENGARUH PEMBERIAN PAKAN SILASE BATANG PISANG (Musa paradisiaca) TERHADAP PERTAMBAHAN BOBOT BADAN DOMBA EKOR GEMUK
}

\author{
Noevetri Zulkarnain ${ }^{1}$, Ir. Wardoyo., MMA ${ }^{2}$, dan Ratna Kumala D, S.Pt,MMG,M.Eng ${ }^{3}$ \\ ${ }^{1}$ Program Studi Peternakan Fakultas Peternakan Universitas Islam Lamongan \\ 2 dan ${ }^{3}$ Fakultas Peternakan - Universitas Islam Lamongan \\ Jl. Veteran No. 53 \\ e-mail: noevetrizulkarnian@gmail.com
}

\begin{abstract}
ABSTRAK
Penelitian ini dilaksanakan pada bulan April sampai Mei Tahun 2018 berlokasi di Desa Pangkatrejo Dusun Tuyuh Kecamatan Lamongan Kabupaten Lamongan. Tujuan dari penelitian ini adalah untuk mengetahui pengaruh pemberian pakan silase batang pisang (Musa paradisiaca) terhadap pertambahan bobot badan domba ekor gemuk. Kegunaan dari penelitian ini diharapkan agar digunakan sebagai bahan informasi dan sebagai bahan alternatif tentang pemanfaatan limbah pertanian berupa batang pisang. Materi yang digunakan dalam penelitian ini adalah 8 ekor domba jenis ekor gemuk, batang pisang, pollard, dedak padi halus, garam, EM4 dan molasses. Variabel yang diamati dalam penelitian ini adalah konsumsi pakan, konversi dan pertambahan bobot badan domba ekor gemuk. Data hasil penelitian dianalisis dengan menggunakan analisis statistik RAK (Rancangan Acak Kelompok). Hasil penelitian yang diteliti dapat disimpulkan bahwa pengaruh pemberian pakan silase batang pisang (Musa paradisiaca) memberikan pengaruh nyata $(P<0,05)$ terhadap pertambahan bobot badan domba ekor gemuk. Perlakuan P2 (30\% Silase + 60\% Konsentrat $+10 \%$ Rumput Lapang) menunjukan hasil pertambahan bobot badan yang signifikan. Hasil penelitian memberikan $\left(T_{\text {hitung }} \geq 0,5\right)$ pengaruh nyata dan $\left(T_{\text {hitung }} \geq 0,1\right)$ pengaruh sangat nyata,sehingga dilakukan uji lanjut menggunakan Uji Tukey HSD dengan menunjukan hasil bahwa perlakuan P2 memberikan perlakuan dengan pengelompokan yang sangat nyata.
\end{abstract}

Kata Kunci : Batang Pisang (Musa paradisiaca), Silase dan Pertambahan Bobot Badan.

\section{PENDAHULUAN}

Indonesia merupakan daerah tropis yang memiliki potensi untuk pengembangan ternak domba. Domba merupakan ternak yang mudah dipelihara dan bernilai ekonomi tinggi. Permintaan pasar terus meningkat terhadap daging domba untuk konsumsi masyarakat selain untuk memenuhi kebutuhan pada saat Idul Adha, daging domba juga dipasok untuk aqiqah, restoran sampai dengan warung sate kaki lima. Populasi domba di Indonesia berdasarkan data statistik tahun 2016 mencapai 15.716.667 ekor dan meningkat di tahun 2017 mencapai 16.462.274 ekor. (Sumber : Direktorat Jendral Peternakan, 2017).

Untuk memenuhi permintaan pasar tersebut, perlu dilakukan suatu usaha ternak domba. Salah satu jenis usaha ternak domba adalah penggemukan, disamping budidaya dan pembibitan. Ternak domba yang cocok digemukkan di daerah tropis salah satunya adalah domba lokal. Domba lokal merupakan domba asli Indonesia yang memiliki daya adaptasi yang baik pada iklim tropis dan beranak sepanjang tahun. Domba lokal memiliki ukuran tubuh yang relatif kecil, lambat dewasa, warna bulu tidak seragam dan hasil karkas relatif sedikit (Sudarmono dan Sugeng, 2008).

Pengaruh iklim sangat menentukan hijauan sebagai pakan. Pada musim penghujan produksi hijauan berlimpah dan sebaliknya di musim kering atau kemarau, hijauan sebagai sumber pakan menjadi berkurang. Untuk mengatasi hal tersebut biasanya petani peternak memberi pakan sisa - sisa pertanian seperti jerami. Ketersediaan hijauan secara kuantitas dan kualitas juga dipengaruhi oleh pembatasan lahan tanaman pakan karena penggunaan lahan untuk tanaman pakan masih bersaing dengan tanaman pangan.

Pakan alternatif yang berasal dar limbah pertanian/industri dapat dipertimbangkan untuk dimanfaatkan dalam usaha peternakan. Ini tidak menjadi suatu yang berlebihan asalkan kita tahu secara tepat nilai guna dan daya gunanya serta tahu teknologi yang tepat pula untuk pengelolaanya. Dalam upaya penyediaan pakan, selain kebutuhan bahan baku yang 
harus diperhitungkan, maka hal ini yang perlu dipertimbangkan adalah dukungan teknologi pengolahan pakan agar peternak dapat mengelola pakan dan mendapatkan hasil yang cukup dan baik mutunya.

Kandungan nilai gizi dari batang pisang adalah bahan kering (BK) 8,62 \%, abu 24,31 $\%$, protein kasar (PK) 4,81\%, serat kasar (SK) 27,73 \%, lemak kasar (LK) 2,75\%, bahan ekstrak tanpa nitrogen (BETN) 40,61 $\%$, hemiselulosa 20,34\%, selulosa 26,64\% dan lignin 9,92 \% (Hasrida, 2011).

Kabupaten Lamongan merupakan wilayah yang akan kaya dengan produksi hortikultura yang melimpah. Dengan meningkatnya kebutuhan akan pangan masyarakat berupa buah - buahan seperti halnya pisang. Kota Lamongan memiliki jumlah tanaman pisang yang menghasilkan 1.867 pohon dan dapat memproduksi pertahun sebesar 2.520,30 ton. (Sumber : Profil dan Potensi Kabupaten Lamongan, 2017).

Pada saat sekarang ini belum banyak penelitian tentang pemanfaatan limbah batang pisang sebagai pakan. Padahal limbah tersebut mengandung komponen-komponen nutrisi yang bermanfaat bagi ternak. Namun demikian, belum diketahui perbedaan kandungan protein kasar dan serat kasar yang terdapat pada pakan lengkap berbahan utama batang pisang.

Penelitian ini bertujuan untuk mengetahui pengaruh fermentasi dari hasil silase bahan pakan segar berupa batang pisang terhadap pertambahan bobot badan harian $(\mathrm{PBBH})$ pada domba di Dusun Tuyuh Desa Pangkat Rejo Kecamatan Lamongan Kabupaten Lamongan. Kegunaan penelitian ini adalah agar hasil penelitian ini diharapkan dapat dijadikan sebagai bahan informasi dan pertimbangan masyarakat terutama petani peternak dalam memanfaatkan limbah batang pisang sebagai bahan pakan.

\section{MATERI DAN METODE}

\section{Materi Penelitian}

Penelitian ini menggunakan domba jenis ekor gemuk sebanyak 8 ekor yang terdiri dari 4 jantan dan empat betina. Bahan pakan yang digunakan dalam proses pembuatan silase dengan perbandingan persentase yaitu batang pisang (Musa paradisiaca) 30\%, dedak padi halus $25 \%$, pollard $40 \%$, molasses atau tetes tebu 5\%, garam 3\% dan EM4 $1000 \mathrm{ml}$.

\section{METODE PENELITIAN}

Metode Penelitian ini adalah metode eksperimen untuk pembuatan silase dengan melihat parameter terhadap pertambahan bobot badan, konsumsi pakan dan konversi.

\section{Variabel yang Diamati}

Variable yang diukur dalam penelitian ini adalah :

1. Pertambahan bobot badan (PBB).

2. Konsumsi ransum.

3. Feed Coversion Ratin (FCR).

Model matematika yang digunakan dalam penelitian ini adalah :

1. Pertambahan Bobot Badan (PBB)

$$
\mathrm{PBB}=\frac{B B t-B B t-1}{t}
$$

2. Konsumsi Ransum

Konsumsi = Jumlah ransum diberikan Jumlah ransum yang tersisa

\section{Feed Conversion Ratio (FCR) \\ $\mathrm{FCR}=\underline{\text { Konsumsi BK (g/ekor/hari) }}$ PBB (g/ekor/hari)}

\section{Waktu dan Lokasi Penelitian}

Penelitian ini dilaksanakan pada tanggal 21 Maret sampai 21 April 2018. Pelaksaan penelitian berlokasi di Desa Pangkat rejo Dusun Tuyuh Kecamatan Lamongan Kabupaten Lamongan. Analisis proksimat dilaksanakan di Laboratorium Nutrisi dan Makanan Ternak di Fakultas Kedokteran Hewan Universitas Airlangga Surabaya.

\section{HASIL DAN PEMBAHASAN}

\section{Kualitas Pakan Silase Batang Pisang}

\section{Uji pH}

Uji $\mathrm{pH}$ yang diamati dalam penelitian ini adalah menunjukan nilai $\mathrm{pH} \quad 4,1$ dengan kategori silase batang pisang memiliki kualitas baik. Menurut MacAulay (2004) bahwa kualitas silase digolongkan menjadi empat kriteria $\mathrm{pH}$ yaitu baik sekali dengan $\mathrm{pH} 3,2-$

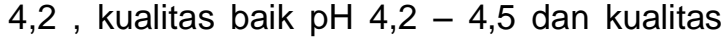
buruk $\mathrm{pH}>4,8$. Menurut Kung dan Nylon (2001) bahwa pH merupakan salah satu penentu dari keberhasilan fermentase. 


\section{Uji Kualitas Fisik}

Uji kualitas fisik yang diamati dalam penelitian ini adalah menunjukan hasil silase batang pisang dengan inkubasi 14 hari untuk tekstur menghasilkan lembut atau lembek, warna yang diperoleh kecoklatan dan bau yang dihasilkan memiiki khas tape ata asam. Menurut Utomo (1999) bahwa karakteristik silase yang baik adalah warna silase yang baik umumnya berwarna hijau kekuningan atau kecoklatan. Sedangkan warna yang kurang baik adalah coklat tua atau kehitaman. Untuk bau sebaiknya bau silase agak asam atau tidak tajam yang bebas dari bau amonia dan $\mathrm{H} 2 \mathrm{~S}$.

\section{Uji Proksimat}

Uji proksimat yang diamati dalam penelitian ini adalah analisis proksimat yang dilakukan di Laboratorium Nutrisi dan Makanan Ternak di Fakultas Kedokteran Hewan Kampus C Universitas Airlangga Surabaya. Tujuan dari analisis proksimat adalah untuk mengetahui kandungan nutrisi yang terdapat pada silase batang pisang (Musa paradisiaca).

Tabel Kandungan nutrisi silase batang pisang (Musa paradisiaca)

\begin{tabular}{lc}
\hline \multicolumn{1}{c}{ Uraian } & Kandungan (\%) \\
\hline Bahan Kering (BK) & 49,67 \\
Abu & 6,37 \\
Protein Kasar (PK) & 6,72 \\
Lemak Kasar (LK) & 6,61 \\
Serat Kasar (SK) & 11,61 \\
BETN & 18,36 \\
ME (Kcal/kg) & 1403 \\
\hline Sumber : Hasil Analisis Laboratorium FKH & HNAIR Surabaya (2018)
\end{tabular}

Pengaruh Perlakuan Terhadap Konsumsi

Tabel Data konsumsi ransum domba ekor gemuk (DEG) selama penelitian (kg/ekor)

\begin{tabular}{cccc} 
Perlakuan & Kelompok & $\begin{array}{c}\text { Total } \\
(\mathbf{k g})\end{array}$ & $\begin{array}{c}\text { Rataan } \\
(\mathbf{k g})\end{array}$ \\
\hline P0 & Jantan & $4.834,3$ & $1.208,6$ \\
& Betina & $5.506,9$ & $1.376,7$ \\
P1 & Jantan & $4.898,1$ & $1.224,5$ \\
& Betina & $5.983,91$ & $1.495,9$ \\
P2 & Jantan & $6.105,2$ & $1.526,3$ \\
& Betina & $5.582,17$ & $1.395,5$ \\
P3 & Jantan & $7.634,63$ & $1.908,6$ \\
& Betina & $5.637,3$ & $1.409,3$ \\
\hline Sumber : Data Primer yang Telah Diolah $(2018)$
\end{tabular}

Hasil Tabel yang diperoleh dari penelitian bahwa konsumsi pada domba ekor gemuk terjadi peningkatan diduga hal ini karena seiring bertambahnya bobot badan domba perminggunya. Meningkatnya konsumsi pakan dipengaruhi oleh beberapa faktor antara lain umur, palatabilitas pakan, aktifitas ternak, energi pakan dan tingkat protein, kualitas dan kuantitas dari pakan serta pengolahannya.

Konsumsi pakan paling tinggi diperoleh pada perlakuan P3 (40\% Silase (SL) + $60 \%$ Konsentrat $(\mathrm{K})+0 \%$ Rumput Lapang $(\mathrm{RL}))$ dimana domba jantan dapat mengkonsumsi \pm $1.908,6 \mathrm{~kg} / \mathrm{ek}$ or dan betina sebesar $\pm 1.409,3$ $\mathrm{kg} / \mathrm{ekor}$. Pemberian pakan yang diberikan pada domba disesuaikan dengan pertambahan bobot badan (PBB), jenis kelamin dan berdasarkan kebutuhannya dengan tujuan untuk mengefisienkan sejauh mana pertambahan bobot badan (PBB) yang dicapai.

Tingkat konsumsi (Voluntary Feed Intake) adalah jumlah makanan yang terkonsumsi oleh hewan apabila bahan makanan tersebut diberikan secara ad libitum. Dalam mengkonsumsi ransum ternak dipengaruhi oleh beberapa faktor yaitu tingkat energi, aktivitas ternak, berat badan, kecepatan pertumbuhan dan suhu lingkungan. Tingkat perbedaan konsumsi juga dipengaruhi oleh beberapa faktor antara lain faktor ternak (bobot badan, umur, tingkat kecernaan pakan, kualitas pakan dan palatabilitas). Palatabilitas pakan dipengaruhi oleh bau, rasa, tekstur dan bentuk pakan yang diberikan (Church, 1988).

Menurut pendapat Rianto dan Purbowati (2010) bahwa pemberian konsentrat dimaksudkan untuk memenuhi kebutuhan pakan sumber protein agar produktivitas ternak bisa optimal sedangkan hijauan (rumput lapang dan silase) dimaksudkan untuk memenuhi kebutuhan pakan sumber serat dan menimbulkan rasa kenyang, serta merangsang mikroba seluitik untuk mencerna serat kasar. Hijauan berupa rumput lapang dan silase merupakan pakan utama ternak ruminansia yang manfaatnya sangat besar, tercemin dari kesanggupan ternak untuk mengkonversikan hijauan tersebut menjadi protein hewani (Hassanuddin et al., 2002). Untuk rasio perbandingan konsentrat dan hijauan untuk ransum domba adalah $60 \%$ : $40 \%$ (NRC, 2006). 


\section{Pengaruh Perlakuan Terhadap Konversi}

Tabel Konversi pakan selama penelitian pada domba ekor gemuk (DEG)

\begin{tabular}{ccc}
\hline Perlakuan & Kelompok & FCR $(\mathbf{k g})$ \\
\hline P0 & Jantan & 15,9 \\
& Betina & 7,3 \\
P1 & Jantan & 26,9 \\
& Betina & 15,3 \\
P2 & Jantan & 9,35 \\
& Betina & 3,1 \\
P3 & Jantan & 9,86 \\
& Betina & 4,01 \\
\hline
\end{tabular}

Sumber : Data Primer yang Telah Diolah (2018)

Hasil Tabel diatas menunjukan bahwa nilai konversi yang diperoleh dari setiap pengelompokan adalah berbeda. Konversi ransum pada ternak merupakan berbandingan antara pertambahan bobot badan yang dapat dicapai oleh ternak dengan ransum yang dikonsumsi. Semakin rendah konversi ransum maka semakin tinggi kemampuan ternak untuk mengubah ransum yang dikonsumsi menjadi daging.

Berdasarkan pendapat menurut NRC (1995) bahwa nilai standar konversi pakan ternak domba adalah sebesar 4 (empat). Hal ini juga terdapat perbedaan dengan iklim di Indonesia yang memiliki iklim tropis dibandingkan dengan standar NRC yang didasarkan iklim subtropis. Karena kebutuhan nutrisi didaerah tropis cenderung lebih tinggi dibandingan daerah subtropis.

Menurut Pond et al., (1995) bahwa perbedaan nilai konversi ternak dipengaruhi oleh kualitas pakan, nilai kencernaan dan pemanfaatan zat gizi dalam proses metabolisme didalam jaringan tubuh ternak. Semakin baik kualitas pakan yang dikonsumsi ternak yang diikuti oleh pertambahan bobot badan yang tinggi, maka nilai konversi pakan akan semakin rendah dan akan semakin efisien pakan yang digunakan.

\section{Pengaruh Perlakuan terhadap Pertambahan Bobot Badan (PBB)}

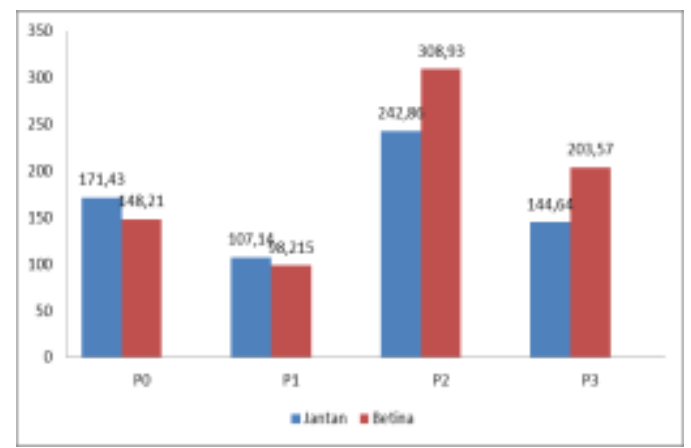

Gambar Rata - Rata Pertambahan Bobot Badan (PBB) Domba Ekor Gemuk

Hasil penelitian diatas pada Gambar diagram batang menunjukkan bahwa perbedaan pertambahan bobot badan domba ekor gemuk yang diberi pakan P0 (10\% Silase $+60 \%$ Konsentrat $+30 \%$ Rumput Lapang), P1 $(20 \%$ Silase $+60 \%$ Konsentrat $+20 \%$ Rumput Lapang), P2 (30\% Silase + 60\% Konsentrat $+10 \%$ Rumput Lapang) dan P3 (40\% Silase $+60 \%$ Konsentrat $+0 \%$ Rumput Lapang). Hal ini dapat dilihat pada pengelompokan berdasarkan jenis kelamin dengan setiap perlakuan. Pada P2 mengalami peningkatan pertambahan bobot badan yang tinggi dibandingan dengan pertambahan bobot badan yang terdapat di P0,P1 dan P3. Untuk jantan dapat meningkat sebanyak $242,86 \mathrm{gr} / \mathrm{ekor} / \mathrm{hari}$ dan betina 308,93 gr/ekor/hari. Hal ini sesuai dengan dengan pendapat Arifiyanti (2002) bahwa dalam mengkonsumsi bahan kering domba yang diberi pakan hijauan berupa rumput lapang dan konsentrat adalah $646 \pm 12,8 \mathrm{~g} / \mathrm{ekor} / \mathrm{hari}$. Sedangkan menurut NRC (1985) bahwa domba dengan bobot badan $10-20 \mathrm{~kg}$ membutuhkan protein 127 - $167 \mathrm{~g} /$ hari untuk pertambahan bobot badan sebesar $200-250$ g/ekor/hari.

Meningkatnya bobot badan pada domba juga dipengaruhi oleh pemberian pakan yang berbeda untuk setiap perlakuannya yang didasarkan dengan pertambahan bobot badan dipengaruhi oleh beberapa faktor antara lain konsumsi total protein yang diperoleh setiap hari, jenis kelamin, umur, genetik, lingkungan, kondisi fisiologis ternak dan tata laksana pemeliharaan (NRC, 1985). Untuk P2 (30\% Silase $+60 \%$ Konsentrat $+10 \%$ Rumput Lapang). Untuk betina dapat mengalami peningkatan pertambahan bobot badannya lebih signifikan dibandingkan domba betina yang lain dikarenakan betina dalam kondisi bunting sehingga untuk kebutuhan akan 
pakan serta nutrisinya lebih banyak untuk dikonsumsi.

Hal ini juga sesuai dengan pendapat Kartadisastra (1995) dalam Reanaldy (2016) bahwa jumlah konsumsi pakan merupakan faktor penentu yang paling penting yang menentukan jumlah nutrien yang didapat oleh ternak selanjutnya mempengaruhi tingkat produksi. Semakin tinggi produk yang dihasilkan, semakin tinggi pula kebutuhannya terhadap pakan. Apabila jumlah pakan yang dikonsumsi lebih rendah dari pada kebutuhannya, ternak akan kehilangan berat badannya disamping itu performanya tidak optimal.

Pada perlakuan diatas menggunakan P2 $(30 \%$ Silase + 60\% Konsentrat + 10\% Rumput Lapang) yang sesuai dengan pendapat Yulianto dan Saparinto (2014) bahwa pakan silase sebaiknya diberikan 25 $30 \%$ dari total kebutuhan pakan ternak.

Pada Perlakuan P3 jantan, tingkat konsumsi pakan cenderung menurun hal ini dikarenakan P3 menggunakan perlakuan $(40 \%$ Silase $+60 \%$ Konsentrat $+0 \%$ Rumput Lapang) yang mana dalam pemberiannya difokuskan untuk penuh diberikan silase tanpa adanya pemberian hijauan atau rumput lapang. Sedangkan untuk PO yang seharusnya lebih difokuskan tanpa pemberian silase tetapi diberikan perlakuan (10\% Silase $+60 \%$ Konsentrat + 30\% Rumput Lapang) hal ini bertujuan untuk mengetahui bahwa dalam penilitan ini ingin mengetahui dari ke empat perlakuan tersebut mana pemberian pakan yang diberikan dapat meningkatkan bobot badan yang tinggi. Karena tujuan utama dalam pembuatan silase batang pisang (Musa paradisiaca) yaitu untuk mempertahankan kualitas hijauan serta mengatasi kekurangan pakan dimusim kemarau dengan melihat ketersedian pakan hijauan segar yang bersifak fluktasi yang mengikuti pola musim. Namun, disamping itu dapat mengetahui bahwa ternak ruminansia tidak bisa lepas pada pemberian pakan berupa hijauan rumput lapang. Hal ini sesuai dengan dengan pendapat Aboenawan (1991) bahwa hijauan berupa rumput lapang merupakan pakan utama untuk ternak ruminansia diantaranya sapi dan domba.

Berdasarkan analisis statistic dapat diketahui bahwa hasil dari Analisis Ragam Pertambahan Bobot Badan pada Domba Ekor Gemuk adalah $(P<0,05)$ berbeda nyata dengan taraf signifikan $5 \%$ maka $\mathrm{HO}$ ditolak $\mathrm{H} 1$ diterima, artinya Terdapat Pengaruh Pemberian Silase Batang Pisang (Musa paradisiaca) terhadap Pertambahan Bobot Badan.

Untuk pengelompokan yang berdasarkan jenis kelamin menunjukan hasil pada taraf signifikan 5\% $(P<0,05)$ menghasilkan berbeda nyata dan pada taraf signifikan 1\% $(\mathrm{P}<0,01)$ menghasilkan berbeda sangat nyata. Sedangkan pada perlakuan terlihat pada Tabel 4.3 menunjukan hasil pada taraf signifikan $5 \% \quad(P<0,05)$ menghasilkan berbeda nyata. Hal ini sesuai dengan pendapat NRC (1985) bahwa pertambahan bobot badan dipengaruhi oleh beberapa faktor antara lain konsumsi total protein yang diperoleh setiap hari, jenis kelamin, umur, genetik, lingkungan, kondisi fisiologis ternak dan tata laksana pemeliharaan.

\section{KESIMPULAN DAN SARAN}

\section{Kesimpulan}

Berdasarkan hasil dari penelitian dan analisis statistik, dapat disimpulkan bahwasanya pengaruh pemberian pakan silase batang pisang (Musa paradisiaca) pada pertambahan bobot badan domba ekor gemuk (DEG) berpengaruh nyata $(P<0,05)$. Untuk pengelompokan menunjukan hasil berbeda sangat nyata pada taraf signifikan $1 \% \quad(P<0,01)$ sedangkan untuk perlakuan menunjukan hasil berbeda nyata pada taraf signifikan $5 \%(P<0,05)$.

Pertambahan bobot badan yang tinggi diperoleh pada perlakuan dan pengelompokan P2 dimana menunjukan hasil kenaikan bobot badan sebesar untuk jenis kelamin jantan diperoleh 6,3 kg dan betina $8,65 \mathrm{~kg}$ selama penelitian (empat minggu).

\section{Saran}

Saran yang dapat diberikan dalam penelitian ini adalah program pada penggunaan pakan silase untuk memperbaiki performa (produksi daging dan pertambahan bobot badan) dapat diberikan untuk ternak domba di Indonesia. Penelitian lebih lanjut mengenai pakan silase perlu dilakukan sehingga pakan silase batang pisang (Musa paradisiaca) dapat digunakan untuk menggantikan rumput lapang dan menjadi pakan alternatif daerah yang kekurangan dalam penyedian pakan ternak.

\section{DAFTAR PUSTAKA}

Aboenawan, L. 1991. Pertambahan berat badan, konsumsi ransum, dan total digestible nutrient (TDN) pellet isi 
rumen disbanding pellet rumput pada domba jantan. Laporan penelitian. Fakultas Peternakan. Institut Pertanian Bogor. Bogor.

Arifiyanti, L. 2002. Daun bawang merah sebagai hijauan substitusi rumput lapang pada ternak domba ekor gemuk lokal. Skripsi. Fakultas Peternakan. Institut Pertanian Bogor, Bogor.

Bappeda. 2017. Profil dan Potensi Kabupaten Lamongan 2017. Pemerintah Daerah. Kabupaten Lamongan.

Church, D. C. And W. G. Pond. 1988. Basic Animal Nutrition and Feeding 2nd.Ed.Jhon Willey and Sons. New York.

Ditjen PKH. 2017. Statistik Peternakan 2017. Direktorat Jenderal Peternakan. Departemen Pertanian RI.

Hasanuddin, A., S. Hasan, \& S. Nompo. 2002. Kandungan bahan kering dan bahan organik rumput gajah (Pennisetum purpureum) yang difermentasi dengan starbio dan urea pada lama penyimpanan berbeda. Buletin Nutrisi dan Makanan Ternak 3 (2) : 25-32.

Hasrida .2011. Pengaruh Dosis Urea dalam Amoniasi Batang Pisang terhadap Degradasi Bahan Kering, Bahan Organik, dan Protein Kasar secara IN VITRO. (Skripsi S-1 Jurusan Nutrisi dan Makanan Ternak, Fakultas Peternakan). Padang: Universitas Andalas.

Kartadisastra, H.R. 1997. Penyediaan dan Pengolahan Pakan Ternak Ruminansia. Kanisius. Yogyakarta.

Kung L. and J. Nylon. 2001. Management Guidelines During Harvest And Storage Of Silage. Proceedings of Tri State Dairy Conf; Fort Wayne, 17- 18 April 2001. Fort Wayne. hlm 1-10.

Macaulay,A. 2004. Evaluating Silage Quality. http://www.afgric.Gov.

Ab.Ca/Sdepartment/depsdocs.nsf//all/fo r4909.html (Nov 2012).

National Research Council. 2006. Nutrient Requirement of Sheep. National Academy Press, Washington.
N. R. C. 1995. Nutrient Requirement of Sheep. National Academy of Science. Washington DC.

National Research Council. 1985. Nutrient Requirement of Sheep 6th. Revised UniEdition. National Academy Press, Washington.

Pond, W.G., D.C. Church \& K.R. Pond.1995. Basic Animal Nutrition and Feeding. 4th ed.John Willey and Sons, Canada.

Renaldy, Edy. 2016. Kajian Manajemen Pakan Terhadap Penggemukan Sapi Potong di Kelompok Tani Ternak Bumi Peternakan Wahyu Utama Sukolilo Bancar Tuban Jawa Timur. Skripsi. Program Studi Teknologi Produksi Konsentrasi Peternakan. Politeknik Agroindustri. Subang.

Rianto , E., D. Anggalina, S. Dartosukarno, \& A. Purnomoadi, 2006. Pengaruh metode pemberian pakan terhadap produktivitas domba ekor tipis. Prosiding Seminar Nasional Teknologi Peternakan dan Veteriner Balai Penelitian dan Pengembangan Pertanian, Bogor. Hal: 361-365.

Sudarmono, A.S dan Sugeng, Y.B., 2008. Sapi Potong. Penebar Swadaya. Jakarta.

Utomo, R. 1999. Teknologi Pakan Hijauan. Fakultas Peternakan Universitas Gadjah Mada. Yogyakarta. 